\title{
Multi Location Disaster in Three Countries: Comparing the Recovery Process in Japan, Chile and New Zealand
}

\author{
William Siembieda \\ $A I C P, P h D ;$ professor, CRP Department.
}

\begin{abstract}
During the 2011-2012 academic year faculty William Siembieda was a visiting Research Professor at the Disaster Prevention Reduction Institute, Kyoto University, Japan, and Research Scholar at the Joint Center for Disaster Research, Massey University, Wellington, New Zealand. His research is represented by this article in which he discusses the recovery processes in three countries after major natural disasters, and the lessons for California.
\end{abstract}

$\mathrm{R}$ ecovery from a large disaster event is a complex process. It $\boldsymbol{Z}$ is a process of life recovery, where part of the past no longer exists and what is the future depends on many decisions that involve people we sometimes do not know. City planners certainly can be of help in the recovery process as usually there are many land use, city design, sustainability, community development, safety and transportation issues involved. While people would like to live in the same place as they did before a disaster, many times this is not possible; so in part, recovery is about inventing the future.

Since 2008, large scale disasters have occurred all over the world including the United States (floods and wildfires), Italy (earthquake), Brazil (landslides), Australia (floods and wildfires), China (earthquake and land slides), Chile (earthquake and tsunami), New Zealand (earthquakes and earth deformation), and Japan (earthquake, tsunami, and nuclear). Thousands of people

Figure 1: Damage caused by reported natural disasters 1975 2010. (source: Center for Research on Epidemiology of Disasters (CRED). 2012. International Disaster Data Base, Catholic University of Louvain, Brussels, Belgium. (http://www.emdat.be/)

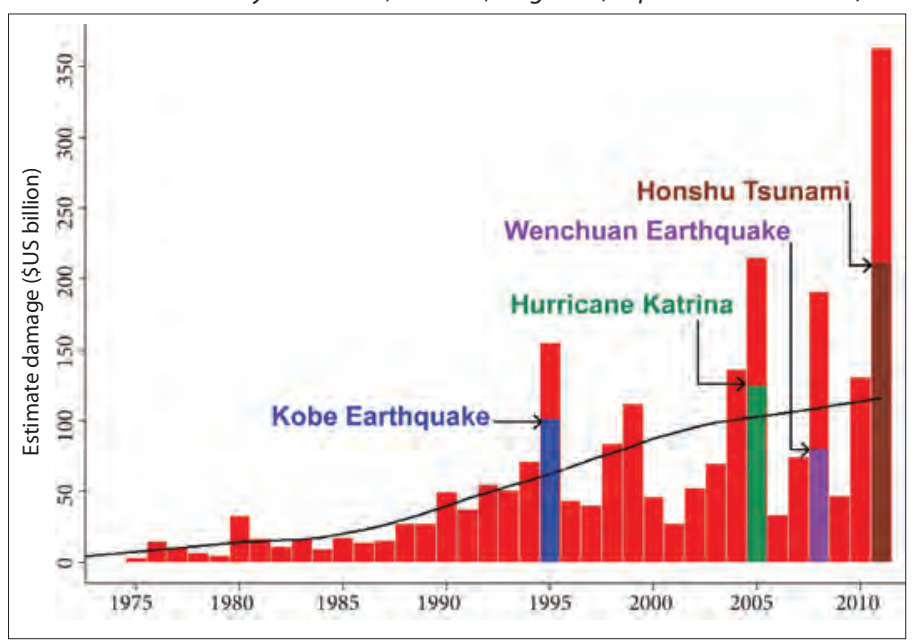

have lost their lives in some of these events and the overall losses and cost of reconstruction is close to $\$ 500$ billion dollars. Increasing damage costs are the trend over the past three decades (Figure 1).

In all large disasters the central (national) government is called upon to provide support in terms of financial and technical assistance, as well to provide a leadership role in designing the strategy for recovery. In less developed countries, central government struggles to provide leadership and resources. In developed countries, the central government plays a major role with direct management of the recovery process or, as in the United States, it supplies funding and technical support. In this way recovery becomes a partnership, however unequal between the survivors (people and businesses) and government. The way the partnerships are formed and carried out determines the path to recovery. These partnerships evolve and adapt to changing conditions in real time.

This article discusses three countries (Japan, Chile, New Zealand) where I visited the disaster areas, spoke to the local people and worked with NGOs and government agencies to understand the recovery process and assist in it. What they have in common is that they have suffered their largest disaster event in modern history between the years 2010-2011, all at the hands of an earthquake. These events also are multilocational, spanning more than a single city, district, or state. They occurred along coastal areas, inland, and in some cases impacted cities for hundreds of kilometers. The vast spatial mix in locations, in topography, in geology, and in impact to historic sites creates complex planning challenges. All of these countries are advanced societies in terms of economic status, functioning democratic practices, and stable governments. They suffer not from threats of war and social conflict, but from multi-natural hazard threats. Can their recovering process make these areas more resilient against future threats and possibly more sustainable? Can design approaches help, and how do planners begin to understand the needs of the local people and help them? 
The time frame used in this paper is two years or less from the initial event(s). This is not enough time for an assessment of comprehensive recovery, but enough time to establish the recovery strategy and the types of partnerships between the survivors and their governments. While each country adapts and recovers in its own way, central government involvement is a constant, although expressed in different ways. While there is a common saying that "all disaster is local," there is also a reality that "all local disaster survivors want the central government to help them with the damage to their lives and property."

While each country has its own story based on its own historical context, all have things in common. They are prone to seismic, volcanic, and tsunami events. For example, Japan experiences $20 \%$ of all 6.0 magnitude and above earthquakes while living on just one percent of the earth's surface. Each country has a long coastline that is subject to tsunami events. There are also clear differences with Japan having a history of at least two thousand years, while Chile (established in 1818) and New Zealand (established in 1840) are younger countries with European roots. Chile was a former colony of Spain with immigrant communities from Italy and Germany, and New Zealand has Anglo-Saxon roots as former colony of England and Scotland. They have differing governmental systems and democratic traditions. All have legal planning systems for the regulation of land use, buildings construction and public safety.

\section{Growing Interest in Disaster Risk Reduction}

The recognition that large scale disasters cause increasing amounts of property damage and extensive disruption to the local economy has led governments in industrialized countries to seek to lower impacts using two major strategies. First are structural measures that strengthen the built environment. Better building codes, higher levees, stronger bridges are examples of such measures. The other strategy is non-structural measures. Avoiding building in a high flood area or on top of an earthquake fault, removing brush from around buildings, and establishing evacuation routes, and buying insurance are examples of non-structural actions. A third strategy also has emerged; it can be called "behavioral." This includes educating people to understand hazard risks and taking some actions to lower impacts.

All of these strategies fall under a broader umbrella called disaster risk reduction. This paper uses a simple three-part framework: assessment, dialogue and action (Wisner et al., 2011). The framework: Assessment, Dialogue and Action (Figure 2) is not linear, but interactive; and I use it in this way. In reality, the components and feedback provide information and iterate. In this way they are a design process. Each, however, requires its own time frame to complete, and can cause (as we see in the case of New Zealand) considerable conflict as to how geo-seismic knowledge is generated and then applied in the dialogue frame.

\section{Assessment}

What caused the disaster in each country and what was its im-

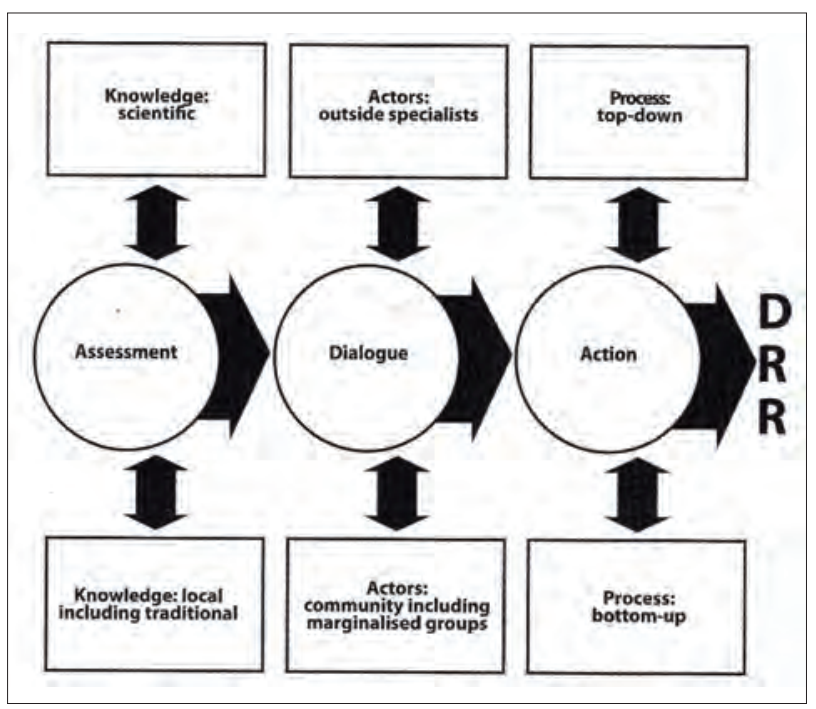

Figure 2. Integrated risk reduction framework. (source: Wisner et al., 2012)

pact? Table 1 provides comparative information on the three countries related to the disaster event. The administrative recovery organization information is shown in Table 2. The Timing of Major Actions is presented in Table 3. These three tables create a disaster profile.

The recovery plan or strategy, issued by the central government, or its recovery agency, envisions a decade of effort. Why ten years is a common number is not clear. Generally most central governments realize that certain restoration actions are required before reconstruction can take place, and that the complexity of recovery in administrative, social, technical and administrative terms simply takes time, more than is usually estimated. Each country faces different technical and engineering challenges. This is an important finding. It establishes that we need to know a great deal about local conditions (geotechnical, topographic, historical) in order to make proper recovery decisions.

Japan, with its earthquake, tsunami and nuclear accident, faces the most difficult challenge of the three. Based on progress in year one, Iwate and Myagi prefectures can meet their ten-year goal. In the Fukushima prefecture it will take at least two generations to complete the tasks of decommissioning the nuclear plants and decontamination of the surrounding areas.

\section{Temporary housing}

With the loss of so many houses due to the tsunami, 55,000 temporary units were built in Japan and installed within three months of the disaster. These are factory built units, assembled on site and fully serviced by power and water. Most of these are scattered site clusters averaging 30-40 units, although some large 100-150-unit groups do exist. In some prefectures, private rentals have been used for temporary units. The central government pays the costs of this temporary housing. While a 
Table 1: Comparison of Japan, Chile, New Zealand earthquakes and related events, damages and costs.

\begin{tabular}{|c|c|c|c|c|c|c|c|}
\hline Country, Date of Incident & Types of Hazard & $\begin{array}{c}\text { Causalities } \\
\text { (Deaths, } \\
\text { Missing) }\end{array}$ & $\begin{array}{c}\text { Major Cause of } \\
\text { Deaths }\end{array}$ & $\begin{array}{c}\text { Housing } \\
\text { Damaged } \\
\text { (Destroyed- } \\
\text { Heavy Damage) }\end{array}$ & $\begin{array}{c}\text { Damaged Cities } \\
\text { and Larger } \\
\text { Districts }\end{array}$ & $\begin{array}{c}\text { Total Estimated } \\
\text { Economic Cost } \\
\text { (\$US billions) }\end{array}$ & $\begin{array}{l}\text { Major Disaster } \\
\text { Characteristics }\end{array}$ \\
\hline Japan, March 11, 2011 & \begin{tabular}{|c|} 
Earthquake - \\
Tsunami \& \\
Nuclear Accident
\end{tabular} & 19.294 & Tsunami, 95\% & 359.000 & $\begin{array}{c}38 \text { cities, } 3 \\
\text { prefectures }\end{array}$ & 235 & $\begin{array}{l}\text { Nuclear accident, } \\
\text { most death and } \\
\text { damage due to } \\
\text { tsunami }\end{array}$ \\
\hline Chile, February, 27, 2010 & $\begin{array}{l}\text { Earthquake - } \\
\text { Tsunami }\end{array}$ & 541 & $\begin{array}{c}\text { Building Collapse, } \\
66 \%\end{array}$ & 190.358 & $\begin{array}{l}52 \text { cities, } 4 \\
\text { regions } * *\end{array}$ & 30 & $\begin{array}{l}\text { Extensive coastal } \\
\text { damage from } \\
\text { tsunami, interior } \\
\text { damaged from } \\
\text { earthquake }\end{array}$ \\
\hline New Zealand, February 22, 2011* & $\begin{array}{c}\text { Earthquake, Land } \\
\text { deformation* }\end{array}$ & 185 & $\begin{array}{c}\text { Building Collapse, } \\
78 \%\end{array}$ & $\begin{array}{c}100,00 \\
\text { damaged, } 60 \% \\
\text { CBD businesses } \\
\text { displaced }\end{array}$ & 3 cities, 1 district & 15 & $\begin{array}{c}\text { Most damage due } \\
\text { to soils failure, } \\
10,00 \\
\text { aftershocks }\end{array}$ \\
\hline
\end{tabular}

* Multiple quakes over nine months, with the Feb. 22, 2011, 6.3 event causing loss of life.

Sources: http://www.stuff.co.nz/national/6394084/February-earthquake-toll-hits-185

http://www.heraldsun.com.au/news/more-news/christchurch-earthquake-among-the-worlds-most-costly

Table 2: Administrative and plans comparison.

\begin{tabular}{|c|c|c|c|c|c|c|}
\hline Country & $\begin{array}{c}\text { Main Entity in } \\
\text { Charge of Recovery } \\
\text { and Reconstruction }\end{array}$ & $\begin{array}{c}\text { Headquarters of } \\
\text { Main Entity }\end{array}$ & $\begin{array}{c}\text { Estimated Years for } \\
\text { Recovery }\end{array}$ & $\begin{array}{c}\text { Assistance for Local } \\
\text { Recovery Plans }\end{array}$ & $\begin{array}{c}\text { Damaged Cities and } \\
\text { Larger Districts } \\
\text { Impacted }\end{array}$ & $\begin{array}{c}\text { Country Population } \\
\text { (millions) }\end{array}$ \\
\hline Japan & $\begin{array}{c}\text { Recovery Agency } \\
\text { Central } \\
\text { Government }\end{array}$ & $\begin{array}{c}\text { Tokyo, country } \\
\text { capital (with 3 } \\
\text { regional offices) }\end{array}$ & $\begin{array}{c}10 \text { (first five years } \\
\text { concentrated } \\
\text { effort) }\end{array}$ & $\begin{array}{c}\text { Local governmen } \\
\text { volunteer } \\
\text { professionals, and } \\
\text { hired consultants }\end{array}$ & $\begin{array}{c}3 \text { cities, 3 main } \\
\text { prefectures, } 5 \\
\text { other prefectures }\end{array}$ & 128 \\
\hline Chile & $\begin{array}{c}\text { Ministry of } \\
\text { Housing, Central } \\
\text { Government }\end{array}$ & $\begin{array}{c}\text { Santiago, country } \\
\text { capital }\end{array}$ & 10 & $\begin{array}{c}\text { Consultants with } \\
\text { local government }\end{array}$ & $\begin{array}{c}52 \text { cities, } 4 \\
\text { regions** }\end{array}$ & 18 \\
\hline New Zealand & $\begin{array}{c}\text { Recovery Agency } \\
\text { Central } \\
\text { Government }\end{array}$ & $\begin{array}{c}\text { Christ Church, } \\
\text { Canterbury } \\
\text { District }\end{array}$ & 10 & $\begin{array}{c}\text { Recovery Entity } \\
\text { NGOs, }\end{array}$ & 3 cities, 1 district & 4,5 \\
\hline
\end{tabular}

${ }^{* *}$ An additional 900 rural villages and communitites suffered damages.

Table 3: Timetable of major actions and events over two-year period.

\begin{tabular}{|c|c|c|c|c|}
\hline Country, Date o Incident & 0-month 6 & Month 6-12 & Month 13-18 & Month 19-24 \\
\hline Japan, March 2, 2011 & $\begin{array}{c}\text { Recovery plan adopted by } 60 \% \text { of } \\
\text { local/prefect. gov'ts, } \\
\text { Central Govt Guidelines issued } \\
\text { All major infrastructure repaired } \\
55,000 \text { temporary shelter units built. }\end{array}$ & $\begin{array}{l}\text { Central Govt Recovery Agency started } \\
\text { First project funds issued } \\
\text { Special Economic Zones funding began } \\
\text { Nuclear restricted zone } 20 \text { km line in place } \\
90 \% \text { of work loss replaced }\end{array}$ & $\begin{array}{l}\text { Specific projects started in cities } \\
\text { Community development plans completed } \\
\text { Renewable energy farm work begun } \\
\text { Rezoning Plan for Fukushima evacuation } \\
\text { areas announced }\end{array}$ & \\
\hline Chile, February 2, 2010 & $\begin{array}{l}\text { National recovery plan issued } \\
\text { National Recovery Council in place } \\
\text { All major infrastructure repaired }\end{array}$ & $\begin{array}{l}128,000 \text { subsidies awarded. }-53 \text { Local } \\
\text { Master Reconstruction Plans and Strategic } \\
\text { Reconstruction Plans completed } \\
\text { Initial expropriate actions taken to create } \\
\text { tsunami barrier areas }\end{array}$ & & $\begin{array}{c}\text { Complete award of } 220,000 \text { subsidies } \\
\text { Start } 155,000 \text { units } \\
\text { Completed } 86,000 \text { units } \\
\text { Direct central gov't projects in small towns }\end{array}$ \\
\hline New Zealand, February 22, 2011 & $\begin{array}{c}\text { Canterbury Recovery Agency (CERA) } \\
\text { created }\end{array}$ & $\begin{array}{c}\text { Christ Church City Council complete } \\
\text { Central City Plan draft. } \\
\text { Draft Recovery Strategy }\end{array}$ & $\begin{array}{l}\text { Government to acquire } 7,000 \text { properties } \\
\text { Regional infrastructure plan complete } \\
\text { Central City Plan draft taken over by CERA } \\
\text { Planning unit. }\end{array}$ & $\begin{array}{l}\text { Replacement of major disaster designe } \\
\text { sewer and water lines begun (This is a } \\
\text { public private partnership.) } \\
\text { Recovery Strategy Finalized }\end{array}$ \\
\hline
\end{tabular}


two-year maximum stay was originally estimated, some areas will need to extend this up to five years due to difficulties in providing buildable sites.

All of the fishing ports along the impacted coastline of Iwate, Myagi, and Fukushima prefectures suffered damages ranging from loss of boats, ropes for seaweed cultivation, to destruction of fish processing factories. After one year, new equipment has been obtained and over $50 \%$ of the fishing fleet has returned to the sea. Due in part to a special government work support program all survivors and evacuees can get employment. There is actually a shortage of labor in the Tohoku region due to all the recover work under way.

New Zealand faces a dual challenge. The Canterbury district, located on the eastern coast of the South Island, experienced a series of earthquakes of large size and thousands of aftershocks over a nine-month period. The accumulation of quakes kept damaging more buildings and caused extensive soil deformation (liquefaction and lateral spread) over large areas of Christ Church's central city and its eastern suburbs. This resulted in the demolition of half of all the buildings in the central business district of Christchurch (the nation's second largest city of 380,000), and its landmark building, the Christchurch Anglican Cathedral, still scheduled to be torn down. Three thousand of the central business districts 5,000 businesses have been closed. The soil deformation is so extensive in eastern residential areas that over 7,000 houses have been declared nonrepairable and will be purchased by the central government. All the homeowners will need to find houses in other areas of the district. This will create a resettlement to areas away from the central city as new housing is built on available green-field sites identified in the Environment Canterbury district growth plan. The central city needs to be rebuilt as an attractive place for commerce, business, tourism, the arts and entertainment. Such an effort means that urban design needs to play a role in economic development as well as "public realm" creation.

Chile faces the challenge of reconstruction of many cities along its coast and also in the interior. For coastal cities, safety from tsunami is the key land planning issue as well as preventing building where there is soil deformation in parts of the major cities of Concepción and Talcahuano. In the interior of the country the challenges are replacement of the thousands of adobe buildings and finding enough land that can be easily supplied with infrastructure services. The third challenge is restoration of the many historic buildings (mostly churches). The desire to restore many historic buildings made of adobe or unreinforced masonry has spawned new research in structurally sound bricks and possibly the use of new plastic sheeting with similar structural characteristics. Until such research can be completed, hundreds of historic buildings remain closed for public use, and will be subject to further deterioration and damage from future earthquakes.

Chile faces a challenge in rebuilding 190,000 destroyed and damaged houses, resettling the survivors living in temporary

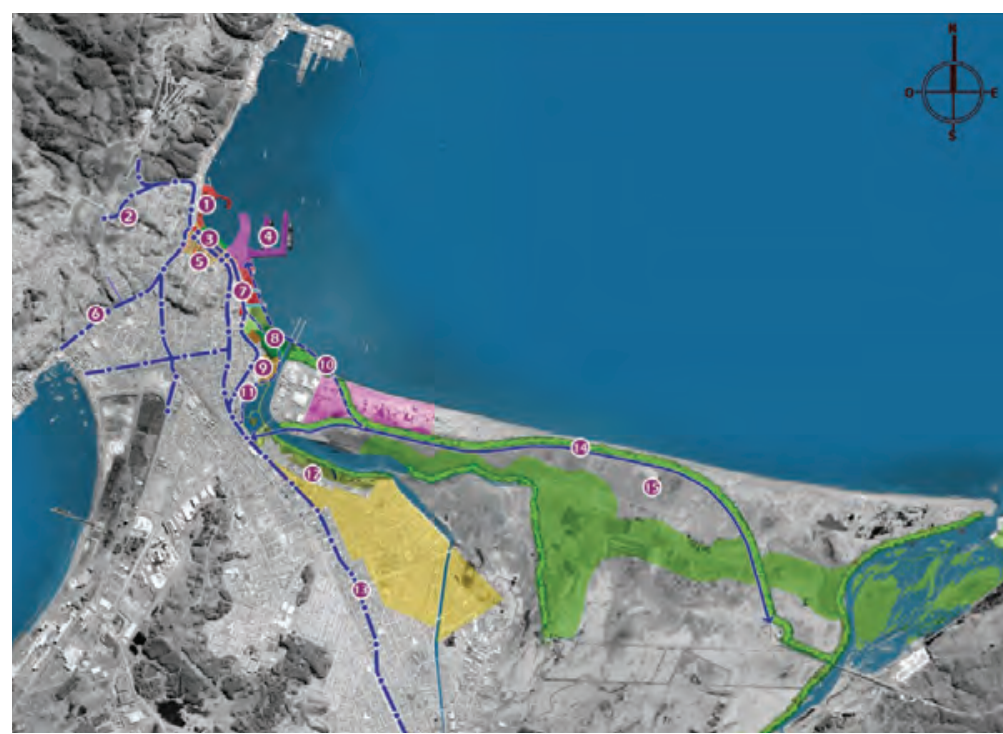

Figure 3: Talcahuano, BioBío province, Chile. Green areas are tsunami protection zones. (source: Plan Región del Bío-Bío 2010-2014, Santiago.

villages (known as Aldeas), and replacing 30,000 units of social housing that do not meet current building codes and are structurally vulnerable. Overall, when built to modern codes, mid-rise buildings have performed well, with a few notable exceptions including two buildings in Concepción, Chile.

\section{Land use, a common thread}

Land use is a central issue in all of these recovery cases, but for different reasons. In Japan the issue expresses itself through location of safe residential areas from tsunamis, because these waves caused the greatest loss of life and mass evacuations. Evacuation safety can be achieved in different ways: moving far away from the risk (avoidance), building sea wall defenses, or providing evacuation strategies for buildings sited in precarious places (e.g. develop strong buildings with protected stairs to reach floors higher than the oncoming waves) (Figure 2).

Figure 4: East Hill Area of Greater Christchurch, landslide and land deformation damage. Note the use of shipping containers as temporary retaining wall. (photo by the author)

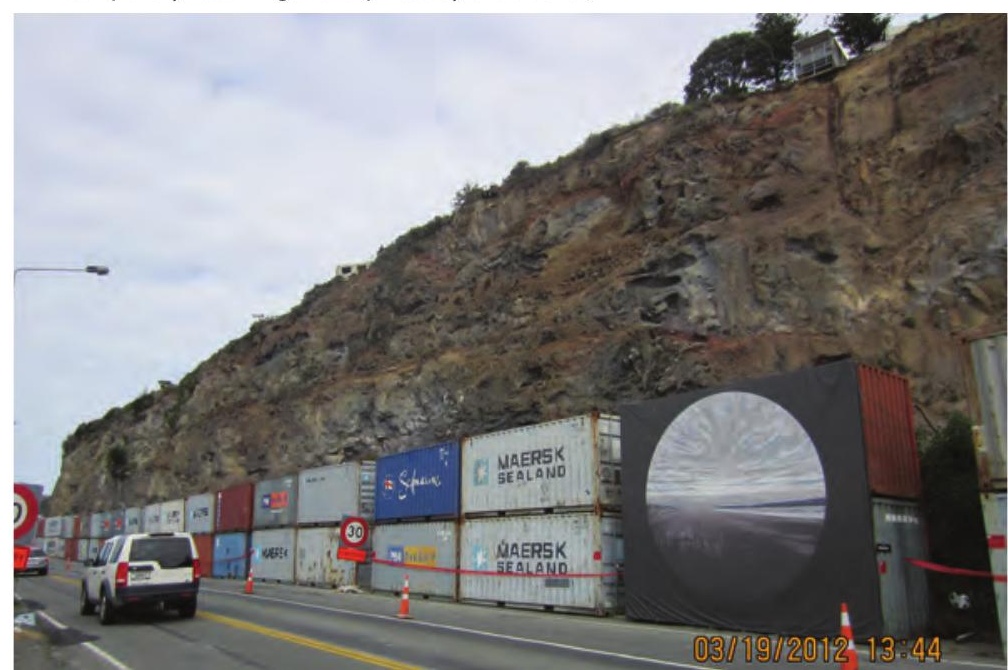




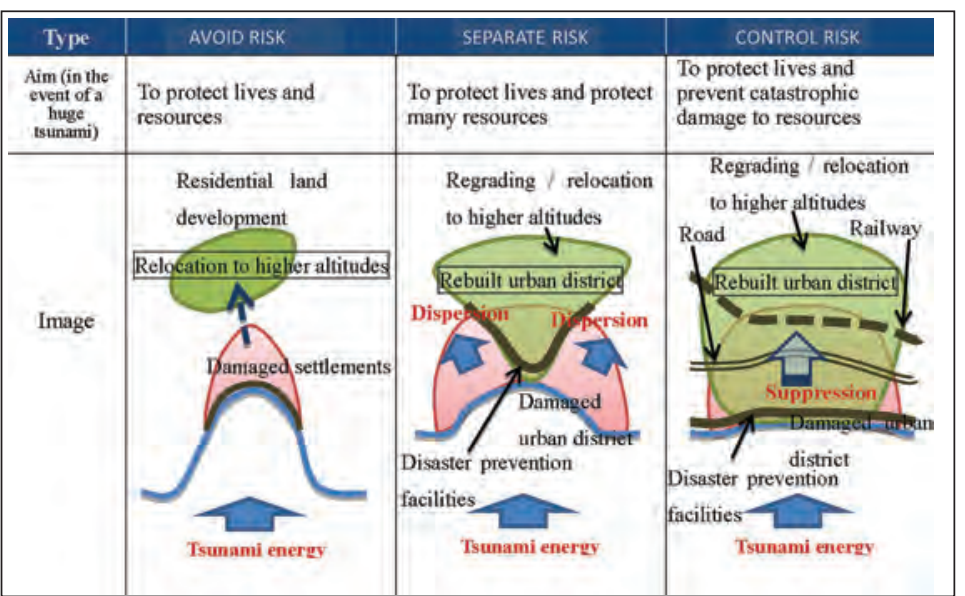

Figure 5. Framework of land use safety schemes. (author's translation of Recovery Plan, Prefecture of Iwate, Japan)

In many Chilean coastal communities the issues of tsunami protection and of liquefaction are present. Again communities are faced with choices. The central government, however, has chosen to implement expansion of sea barrier open parks through expropriation of houses close to the ocean in at least the following towns: Dichacto, Constitución and Talcahuana (Figure 3). In each case, the people losing their homes were against this, but were compensated at full value of their house and land. Conducting the expropriation does take time and was required before housing was rebuilt in nearby areas with less tsunami risk.

The Canterbury region of New Zealand faces a series of land use issues, the largest being land damage from the earthquake causes liquefaction, vertical land level changes (e.g. streets higher than the driveways into adjacent houses) and lateral spreading under thousands of houses. Within one year, 100,000 properties were surveyed for land damage. A cordon placed around the central business district forced many businesses to close, even if the buildings they occupied suffered less than terminal damage (Figure 4). Private companies working for the central government recovery agency determined the extent of liquefaction and damage to a property. More than half of the 2,400 buildings in the central city area were severely damaged. In the end it was the Canterbury Earthquake Recovery Agency that decided land use suitability and zoning. The local municipality had a secondary role in this process.

In Japan, while the earthquake caused damage to pre-1981 built houses, overall it was minor. The major damage was caused by the tsunami. Thus all town and prefecture recovery plans address the need for more safety. The three main strategies for this are shown in Figure 5: Avoid Risk, Separate Risk and Control Risk. This is the central premise of all built environment recovery and community development plans.

\section{Dialogue}

This is the phase where a discussion of who does the recovery planning occurs. It includes issues of what to do (as the assessment of damages is hopefully complete), how to do it, who pays, what standards need to be applied, what are the principles of recovery, and who benefits from the process.

The question of who does the planning is tied to some fundamental relationship between the central government and the local community (the survivors and their local governments). In multi-locational events that include many cities and towns this can be a complex discussion. What one town wants may be not what another wants or needs, especially if there are lots of towns involved. Who decides where the resources will be allocated? The comparative data in Table 2 speaks to this point in terms of the very large number of impacted cities in Chile and Japan.

Chile

Chile and Japan used community plans as a stepping stone for initial dialogue. The Chilean government provided funds and consulting support for two regional efforts to create municipal recovery plans. One effort was in the Bío Bío Region, where the regional governor facilitated the design of 18 master plans for cities. Concepción, the region's largest city conducted their own separate process. These plans, developed under the guidance of regional staff and consultants, worked with the local people to create a vision for reconstruction and identified the most important projects and areas that needed to be addressed. The plans however are not legal or binding documents. They are advisory to the local government, but could be adopted and integrated into the legal master plan. These plans also form the basis for a further level of discussion on specific areas and projects. These plans can also introduce hazard and inundation maps.

The second Chilean plan effort provided funding for 27 recovery plans to cities in the O'Higgins and Maule regions conducted with the assistance of a team from the Pontificia Universidad Catolia de Chile (PUC). Coastal plans and inland plans were developed along with extensive analysis of the geotecnical status of the communities. These plans, like those in Bío Bío are advisory to the local towns. All of these plans had a citizen participation component and various levels of consult support. In at least three coastal towns the plans called for risk avoidance through expropriate of areas close to the ocean.

Additional strategic recontruction plans were made for larger interior cities such as Talca and Curició. The Talca strategic plan was made with donated private funds, the assistance of a private consultant, under an agreement with the city government, the regional governor, and the housing ministry. The Curició plan was also conducted by a private consultant with donated funds, as well as from a local government and regional governor agreement. All of these plans have a public participant component, but none give local community (neighorhood) groups shared governance in the plan making process. The community input is consultative. 
Japan

In Japan, all cities in the impacted Miyagi and Iwate impacted prefectures, along with the prefectures, developed their own plans within six months of the 2011 tsunami. These plans were made with a mixture of volunteer professionals, consultants and local residents. There was no central government oversight in the plan making process, and the central government provided funds for consultant support in each municipality. Volunteer professionals from outside the community have played important roles in helping local neighborhoods sort out complex technical issues related to seawall heights, elevation of land for relocation areas, and population projects related to the need for public buildings such as schools. The continued level of volunteer support in Japan is impressive and useful, especially as many survivors are living in scattered temporary shelters.

The central government's Basic Guidelines for Recovery, issued four months after the tsunami, calls for a model that places the project planning at the municipal level and the project funding at the ministerial level. The plan sets down the town's principles and vision. Overall, they call for the following: ensuring safety, rebuilding lives, and expansion of technology and natural resource based industry. The basic land use proposals generally are built around a chosen risk avoidance strategy. The plans function as the basis for developing specific recovery projects.

There are many small bays along the varying topography of what is called the Sanriku Coast. In each bay there is usually at least one village, and some municipalities are composed of many bays. There is a real planning challenge, as shown in Figure 6, where four towns were merged in 2005 to create Minanisanrikucho. Plans are needed for these smaller areas, each with its own culture, economic base and land use and hazard profile.

\section{New Zealand}

The New Zealand dialogue takes a different form. The central government created the Canterbury Earthquake Recovery Agency (CERA) with extensive powers to conduct the recovery planning for the district (that contains three cities and a district authority). The authority is located and operates from Christchurch. Christchurch, the main city in the region, was tasked with developing only a Center Business District (CBD) Recovery Plan. The recovery strategy is developed by CERA itself, along with directing a special infrastructure reconstruction group known as Stronger Christchurch Infrastructure Rebuild Team (SCIRT), a multi-jurisdictional public-private group for major infrastructure recovery, including a new wastewater plant, which incorporates hazard mitigation design.

The city of Christchurch ran an extensive plan-making process for the central city, with the assistance of an urban design consultant from Europe, and completed a series of community workshops and input sessions that yielded 104,000 suggestions from people in the region. This plan was not adopted by the Christchurch City Council, but was sent to the central

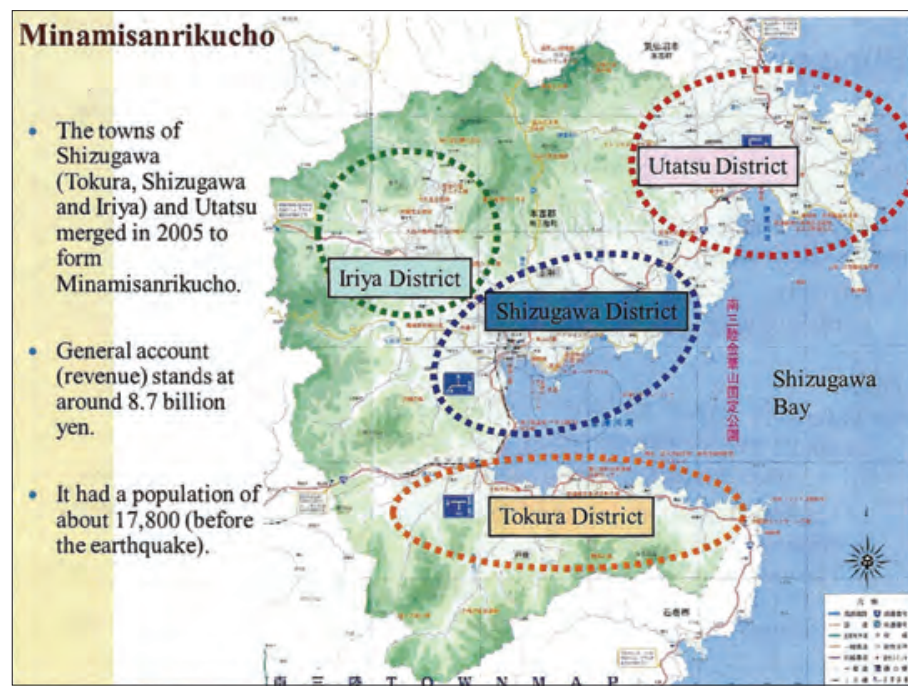

Figure 6. Minamisanrikucko, Myagi Prefecture, Japan. (source: Ishikawa 2012a)

government earthquake minister for review. The Minister has responded by calling for a special planning unit to be established to propose a set of feasible projects in the CBD. The city's CBD plan has not moved forward.

\section{Action}

Hopefully in this phase the decisions made in the other phases of the framework lead to the allocation of resources (human, governance, fiscal and physical) and action. In these countries there exists a tension between central government ministries and local government related to how, where and when recovery occurs. This can lead to friction, as a local urban design project will wait for funding until a larger regional transportation improvement effort is completed. All of the countries presented have made progress towards recovery, but in different ways.

Figure 7: Proposed Reconstruction Zoning in Shizagawa District, Minamisanrickuho Municipality, Miyagi Prefecture, Japan. (source: Ishikawa, 2012b)

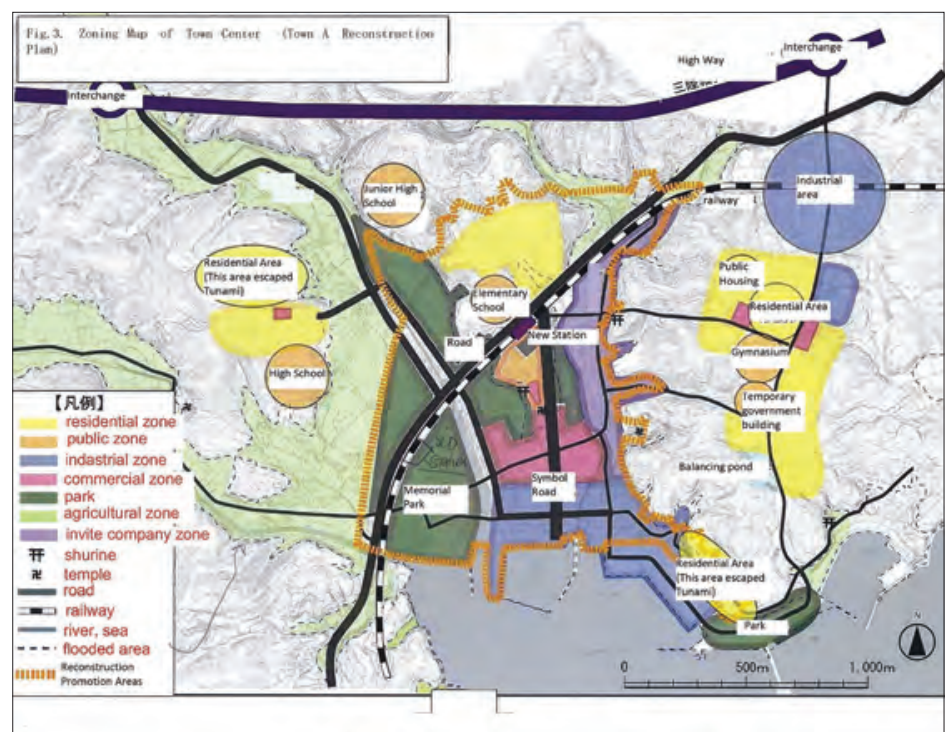


Chile

Chile has been engaged in recovery for two full years. Among the actions taken are: rapid establishment of recovery funding, a housing subsidy program, local planning efforts, assistance to the fishing areas, and a separate effort for reconstruction of historic buildings. The central government approved a multi-billion dollars recovery budget. The division of labor to selected ministries was quickly assigned and a plan for reconstruction issued six months from the time of the disaster. The model used by the central government for housing reconstruction involves subsidies to low and modest income people who lost homes, with the construction being done by the private sector. The private sector is to obtain building permission from the local government. Local government is charged with being the gatekeeper for where to build, and also is the entity responsive for determining if the site is safe and can obtain needed infrastructure services (water, power, etc.). The private utility providers completed major infrastructure recovery within three to twelve months.

At the end of the first year, 128,000 subsidies had been given, and by the end of the second year, all 220,000 were awarded (see Table 3). Transforming the subsidies into actual houses rested with the basic choice of using a market driven model and a local government gatekeeper model. Some cities have been only able to give permits for twenty houses. Due to the lag in performance, two years after the event, national legislation was passed allowing the regional office of the Housing Ministry to provide direct assistance to some cities in order to increase housing production. This assistance will be done with the cooperation of local government, but the technical issues, including issuing needed permits, will be managed by the regional office (Regional Secretariat for Housing and Planning). This action decreases the level of decentralized (local) control over the process, but will get more housing built.

Criticism of the Chilean experience includes lack of community input, poor design solutions for replacement housing in such towns as Talca, and expropriation of lands adjacent to the Pacific Ocean instead of a sea wall of sea barrier solution. Overall the recovery has tested the capacity of local government to respond more than the capacity of central government to lead. Criticism over vernacular design solutions may not be well founded as each local government has final approval of projects.

\section{Japan}

During the sixteen months since the 2011 tsunami, Japan has been faced with stabilizing a nuclear accident, building 55,000 units of temporary houses, making new estimates of its earthquake predication and tsunami models, creating a central government reconstruction agency, and committing multi-billions of dollars in recovery assistance. Within nine months, $90 \%$ of the work lost had been replaced (through a combination of getting employers back in business, new business and recovery job creation schemes). The reconstruction agency is called the "one-stop shop," however, it is the separate ministries that draw up the guidelines for project applications and control resources. (This includes the most powerful agency, the Ministry of Land, Infrastructure, Transport and Tourism.) While it is a bottoms up process from the local level, the issuing of project funds is a top down process. This process worked well enough to issue 2.5 trillion yen in combined support less than one year after the event, with $44 \%$ of the funds being housing related.

Uncertainty is the operative word about the long-term outcome of the Fukushima Dai Ichi nuclear plant clean up and remediation of surrounding lands. The nuclear plants remain unstable and present a difficult decommissioning task. This is being addressed by a separate new nuclear commission under the Ministry of the Environment, and is outside the purview of the Reconstruction Agency. In sixteen months, a plan for rezoning the towns that fall under the evacuation zone has been developed, and a program to purchase properties within the restricted zone as well as compensation for loss of livelihood has been established. Japan's Act on Compensation for Nuclear Damage (1961), in its infancy, places no cap on the operator's nuclear liability.

\section{New Zealand}

The New Zealand situation reflects various levels of complexity. After twenty months, technical analysis of the areas in the Canterbury region with soil damage have been completed and all neighborhoods know if they can rebuild or not. While the

Figure 8: Christ Church Central City; proposed "Frame Plan". (source: Christchurch Central Recovery Plan; (ERA website)

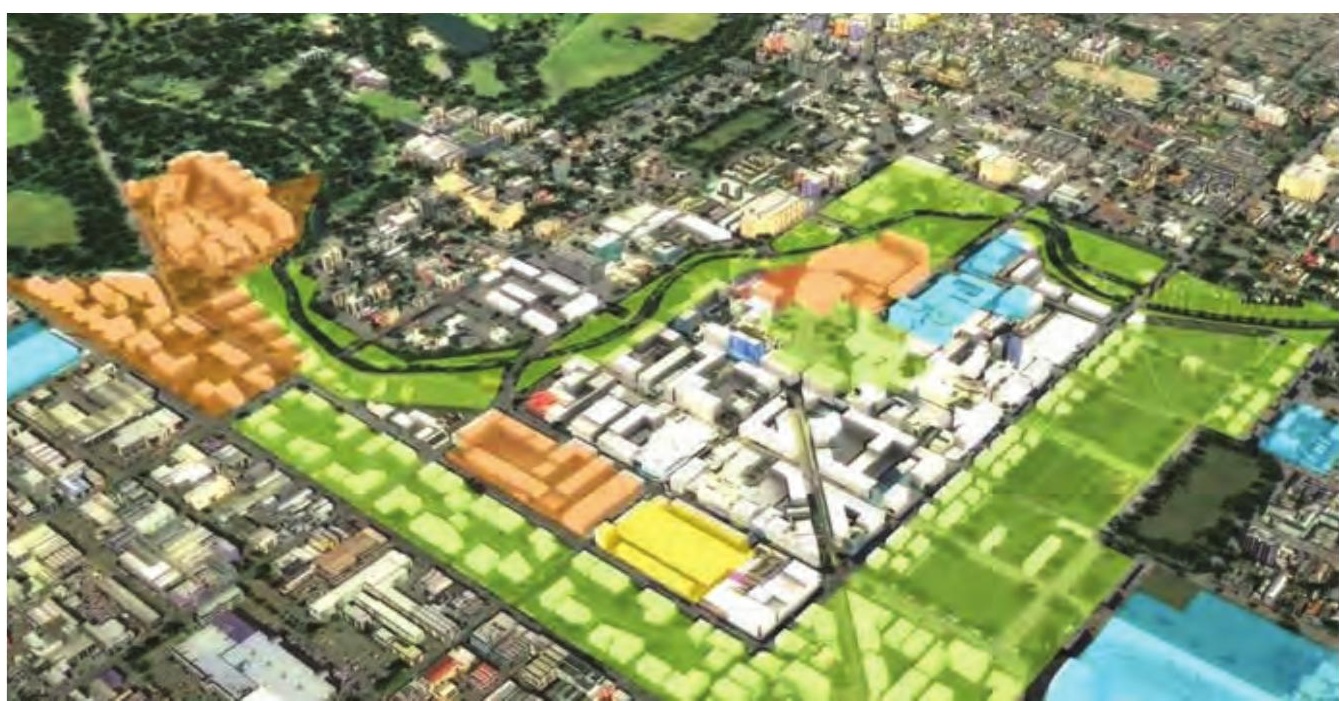


government has acquired almost half of the "7,000 red zone" properties, the other half are still being processed. This is a difficult and time-consuming process because some people do not wish to sell out to the government even though remaining there means having no infrastructure services provided. The final agreements between the Earthquake Commission (the Crown insurance entity) and the reinsurers are still to be made. SCIRT is doing well in forging new levels of partnership governance for DDR infrastructure in the region. This means the engineering focus is now on mitigation of risk, not on cost containment. This is a significant step forward in holistic recovery.

The final CERA Recovery Strategy document and a central city development plan was announced in August 2012. This plan is the result of New Zealand consultant consortium of design and project management professionals, and will focus on a defined central city area. It is here that urban design should make its best contribution. This plan will replace the one drawn up and adopted created by the Christ Church City Council in December 2011. This plan reflects the power of CERA as an extension of the central government and also a rejection of the previous plan making process.

The New Zealand insurance scheme is unique in the world and complicates this recover. Over $90 \%$ of the country's population holds seismic insurance coverage for the house, the contents and the land under the house. This large coverage is possible as the seismic insurance is a required add-on to fire insurance, which most people buy. There are two payers of the coverage in case of a claim: a government agency known as the Earthquake Commission (EQC) and private insurers (local companies and re-insurance companies). The EQC is liable for the first $\$ 100,000$ of property damage (including land damage) and $\$ 20,000$ in personal property. Claims above this amount are to be paid by the private insurer. Because there were so many earthquakes in the area, some 459,000 claims have been filled to date and a total of \$AU 3.77 billion have been paid as of October 1, 2011. This is almost twice the total residential housing stock $(220,000)$ of the Canterbury area. The high number of claims is due to multiple earthquakes. New Zealand is unique in the world in this type of seismic coverage, where the vast majority of people participate. For the most part this makes it far easier to address the permanent housing replacement needs. The challenge for planning is where to locate the permanent housing.

The Recovery Strategy focuses on identifying work to be programmed. This work is linked to a set of nine CERA priorities, the top five being: safety and well being, investment conditions, infrastructure repair, supply of land for recovery needs, and coordinated work across central governments, local authorities, insurers, and the private sector.

\section{Discussion}

All of these countries have made people's safety the first pri- ority. Each is using land use controls, new building codes and improved standards for location of shelter, commerce and civic structures in creating the new urban form for the multitude of cities that need assistance.

Due to the nuclear accident, Japan faces the most complicated recovery task, but it has the most contemporary experience with recovery and a national consensus to rebuild livelihoods as well as the built environment. In many ways Chile has recovered quickly, and has provided its cities and towns with new technical information on which to make future land use decisions. After eighteen months of deciding where not to build, and a commitment to mitigation of its infrastructure risk, Christ Church is ready to rebuild. It still faces challenges of paying to rebuild confidence that it is a safe place. Each has used a different government-civic-private sector model, in part based on its fiscal capacity and its legal and cultural views of recovery.

All, in a real sense, look towards the market (the private sector) for positive long-term recovery. All, in some way, have also realized that all levels of government have a special responsibility to protect its people. Hopefully they will take this lesson to heart and prioritize safety for the homes and well-being of people.

\section{References}

Christchurch Earthquake Recovery Authority (CERA). 2012. Christchurch Central Recovery Plan. Christchurch, NZ: CERA: Central Development Unit.Government of Chile. 2011. Plan Región del Bío-Bío 2010-2014. Santiago, Chile.

Ishikawa, Eiko. 2012a. Damages Caused by the Great East Japan Earthquake and Rehabilitation Plans. Powerpoint presentation at the Disaster Reduction and Human Renovation Institution, Kobe, Japan.

Ishikawa, Eiko. 2012b. The Process of Drawing Up Reconstruction Plans in Extensive Disaster-Hit Areas: Including Community Relocation and Challenges in the Implementation of Plans. Working Paper. Disaster Reduction and Human Renovation Institution, Kobe, Japan.

Siembieda, W., Johnson, L.C., and Franco, G. 2012. Rebuild fast but rebuild better: Chile's initial recovery following the $27 \mathrm{~F}$ earthquake and tsunami. In Earthquake Spectra, Journal of the Earthquake Engineering Research Institute (ERRI), June.

Siembieda, William, Haili Chen, and Norio Maki. 2012. Multi-Location Disaster: Shaping Recovery in the Great East Japan Earthquake and Tsunami of March 2011. In Urban Planning Forum (in Chinese); November. Forthcoming.

Wisner, Ben; J.C Gaillard \& Ilan Kelman (eds.). 2012. Handbook of Hazards and Disaster Risk Reduction. London: Routledge Publications. 